\title{
Analysis of Archetypal Character Jim Casy in The Grapes of Wrath
}

\author{
Yanhong Fan \\ Changchun University of Science and Technology, Changchun, China
}

\begin{abstract}
The primary concern of the present thesis is with the archetypal qualities of The Grapes of Wrath. John Steinbeck constantly uses references and allusions from Greek mythology and Bible. According to Northrop Frye's definition of archetype, there exist archetypal characters. The major character of The Grapes of Wrath is Jim Casy who lead the Joads and other people to probe the new land. It is obvious enough that Jim Casy is a notable Christ figure in this novel. His Christ-like prophet function is verified in quite a few ways. He is clearly a modern Christ figure, and he fulfills this identity through both his words and actions. The new messiah arrives in a rich context of tradition Christian symbology, and his messages, like that of Christ, are one that considerably broadens man's sense of spiritual community.
\end{abstract}

Index Terms - archetypal criticism, archetypal character, Bible

\section{INTRODUCTION}

As we know, archetypal criticism is a powerful study in the history of recent literary theory, especially from the 1950s to the 1970s. Its critical strategy is to back up from the text, to find the underlying correspondences or analogues in works throughout the world so as to apprehend the recurrences of certain archetypal characters, narrative patterns and motifs. Hence, the power and significance of works of literature, or of the whole of literature is explained. In literary criticism, this term archetype means "character-types, recurrent narrative designs, patterns of action, images and motif or themes which are identifiable in a wide variety of works of literature, as well as in myths, dreams and even social rituals." (Jung, 1996, p115) The word "archetype" originates from a Greek word "archetypos". Arche means "root "and "origin" while typos "pattern" or "model". In Plato's opinion there exists the world of Idea that is perfect and eternal and can be known only through the mind, not through the senses. The object that we see and feel through our senses is merely pale and imperfect copy of the ideal forms he called "archetype". The major influence on mythological criticism is Carl Jung. Jung believed, contrary to eighteenth-century Lockean psychology that "Mind is not born as a tabula rasa (Jung, 1996, p115)." He expanded Freud's theories of the personal unconscious, asserting that beneath this is a primeval collective unconscious shared modern man with his primeval roots. The contents of the collective unconscious are called archetypes. Jung also treats them as dominants, images, mythological or primordial images, and a few other names, but archetypes is the most important one. So the collective unconscious is manifested in the recurrence of certain images, stories and figures, called "archetypes" which is "the psychic residua of numberless experiences of the same type." Jung indicated that myths are the means by which archetypes, essentially unconscious forms, become manifest and articulate to the conscious mind and they find themselves in the individuals' dreams. Jung perceived an close relationship among dreams, myths and art because all this three factors serve as media. And this media will go through the archetypes and become accessible to consciousness. Jung observes that the man who possesses the primordial vision, a special sensitivity to archetypal patterns and a gift for speaking in primordial images that enable him to transmit experiences of the "inner world" to the "outer world" through his art form Modern Man in Search of A Soul. According to the his materials, Jung said that it is only logical that the artist "will resort to mythology in order to give his experience its most fitting expression." (Zhugang, 1997, p164)Here we can know that Jung examines the subject from psychological aspect. His theory of Collective Unconscious exerts a strong influence upon modern writers such as T.S. Eliot and D.H. Lawrence.

There are many ways to read The Grapes of Wrath. To some it is simply a story about a group people's journey; to others it is interpreted as a book about the lives of ordinary people striving to preserve their humanity in the face of social and economic desperation. Several different theories have been presented, explaining Steinbeck's use of symbols. What many seem to have overlooked is what he answers is right there in front of them. The Grapes of Wrath won the 1940 Pulitzer Prize eventually became the corner stone of his 1962 Nobel Prize award. It is a pity to have neglected the study of mythological criticism, or in other name, archetypal criticism when we studied John Steinbeck who uses mythological and biblical images, characters, narrative patterns, and motifs in his literary creation. From this new perspective, we can better appreciate this masterpiece in literature. Although my thesis is only a tentative study on this subject, it is based on the former studies and is not an isolated blind leap in the dark. In this thesis, the author only choose to analysis some archetypal parts: archetypal characeter Jim Casy and archetypal images.

\section{ARCHETYPAL CHARACTER FROM THE BIBLE}


The major character of The Grapes of Wrath is Jim Casy who lead the Joads and other people to probe the new land. The reader's sense of the role played by each of this figure will shape that reader's experience with the book. From the angle of literary critic, I'll discuss it within the frame of archetypal critical theory. Bible is the arsenal of western literary. Numerous western writers make the best of images, characters, plots, motifs, themes and spirit of the Bible. So dose the author of the The Grapes of Wrath ---John Steinbeck. A great deal of Biblical characters appeared in this novel. Of course is that of Christ, represented respectively in the novel not only by Jim Casy but also by Tom Joad and even Rose of Sharon. But the most obvious character is the Jim Casy. From The New Testaments of the Bible, we know that Jesus Christ is born in Bethlehem of Judea and grows up in Nazareth of Galilee. His religious activity begins after his baptism. At that time John the Baptist is preaching around this region. He is preparing for his believing of the coming of the kingdom of Heaven. He calls for all the Jews to repent of their sins and then gives them the action of baptism. Jesus Christ fully agrees to John's opinion. After his baptism given by John the Baptist, Jesus Christ begins his preaching of the coming of the kingdom of Heaven in the villages and towns of Galilee. His action can be divided into two parts: one is to preach the gospel of the kingdom and the other is to heal every disease and every infirmity of the people. Actually the purpose of all these two parts is to let the people know that they are sinful, that they must confess their sins and that they must repent of their sins. Then by these Jesus Christ wants the people to have a good preparation for welcoming the coming of the kingdom of Heaven. The most severe sin in all people's sins is pride. That is to say, there is no courage in people to confess their own sins rather than know that there is a demand of repenting of own sins. So healing the diseases is just a symbol of recurring the people from the body and spirit.

Jesus Christ has traveled many places to preach his believing and cure so many people from the disease. But to Jesus Christ the most important step is to preach in Jerusalem, the holy place to Jews, in face of the leaders of Jews. It is really a dangerous step to Him. In the past some Israel prophet had been killed just because their preaching against the polices of the government in Jerusalem. Jesus Christ knows that very well. But he still persists in walking into Jerusalem and doing his preaching. He points out the misuse of the temple of God, warned elder of the people, chief priests and scribes, says to Pharisees their seven "woes" and prophesied the future tribulation. Although Jesus faces the death, he still believes his doctrine. So we can see Jesus Christ is a pious prophet. He just likes a scapegoat who sacrifices for human being's happiness. Only through Jesus' death and resurrection, can people become believers of God and know that only when they confess their sins and repent of their sins, can their souls be accepted in the Heaven after their death.

\section{ARCHETYPE OF JeSUs CHRIST}

The figure Christ, must be remembered, usually appears as a forerunner, as a leader, and as a sacrificial figure. His death would give human beings a new beginning and a new chance. Jim Casy, one of the most important characters in the novel has the obvious eye-catching initials, J.C., which is a reminiscence of the name of Jesus Christ. Prior to our meeting with him, he has spent his life embattled with Satan just like a Calvinistic fire-and brimstone fundamentalist. He tells Tom Joad: "Here's me that wuse to give all my fight against the devil's cause I figured the devil was the enemy. But they's somepin worse'n the devil got hold a the country." And like Christ, he has also gone into desert to wrestle with has faith. Just like Casy himself put it, "Here's me, been a goin' into the wilderness like Jesus to try find out somepin” He also says that: “I ain't sayin' I'm like Jesus.... But I got tried like Him, an' I got mixed up like Him, an' I wen into the wilderness like Him.... Sometimes I'd pray like Ialways done. On'y I couldn' figure what I was prayin' to or for. There was the hills, an' there was me, an' we wasn't separate no more. We was one thing. An' that one thing was holy."( Steinbeck, 2000, p478)

Like Christ, Casy has discovered within himself a commitment to mankind as well. In chapter four, when Casy explains his new philosophy of life to Tom Joad he says, "I got the call to lead the people, an' no place to lead' em." During the long voyage to California, Casy accompanies the Joads because he wants to be with people and help them, although he does not know how he can act usefully on their behalf. So the strong basis upon which his philosophy is based is his unique love of people. And Casy's strong love of people embodies in his commitment to help the Joads when he gives himself up to the Deputies at the Hoover Ville in order to protect Tom from being arrested. For it will be a disaster for the latter to go prison because of having broken the parole. This substitution of his own bodies symbolically, his life for Tom to go to prison, to "save" Tom, is a Christ-like behavior which qualifies him to be a martyr for his own people. So it is the movement from Bible-belt evangelism to social prophecy that constitutes the development of Jim Casy. At the beginning of the novel, he has already left preaching and has returned from his sojourn in the hills. His way out of a mess of troubles. But although Casy is already approaching his revolution, it is only through his experience with the Joads that he is able to complete his vision. So he moves form the purely speculative to the pragmatic, from motionlessness to action. Twice in the novel, Casy is described as glowing with light. The second time, just before he is killed, he is described as "That shiny bastard". And the night before his death the rooster crows which recalls the rooster that crowed before the Crucifixion. And Casy's Christ-like development is complete when he is pointed out as "That shiny bastard" and struck on the head with a pick handle.

\section{The Similarity BetweEn Jim CASY AND JESUS Christ}


Jim Casy is former preacher and long-time friend of the Joads, the most important character of the novel. However, it is surprising that he, as one of the most important characters in the The Grapes of Wrath, along with Tom and other members of the Joad family, disappears till in about one-third part of the novel. But we can't forget him because the Joad family always reminds us of him time by time. Both Tom and Ma often repeat Casy's ideas and words and talk more about his personality.

Casy takes his duty. What he says rather than what he does. He has many words. As a former preacher, he likes talking, but now he has given up his career as a Jesus Christ, with whom he shares the same initials, J.C., Jim Casy declares his rejection of conventional religious notions of sin, hellfire, and emphasizes the salvation of Christ, Jim Casy also shares a lot of other characteristics, such as Casy's sacrifice of himself to save Tom and Flody. Moreover just like Jesus Christ's criticism against the leaders of Jews in Jerusalem publicly at that time, his giving up John the Baptist's belief and beginning to preach the gospel of love, Jim Casy also betrays his ever believed religion, the Christianity and gives up the position as a priest and walks into the poor to preach his new worldly belief.

Though Jim Casy says that everyone is sinful, but in his heart he feels that this is a thing he can't understand. In this severe reality he tries to find out a new belief rooted in human being's general need. He claims that he will approach to the common people and that he does not want to teach them something but wants to learn something for himself like the couple's love, the emotion of raising children and mutual helping and practical poetic communication between people. All these are Jim Casy's new maxims. Like Jesus Christ with his twelve disciples having a long trek in order to save human being from their sins, Jim Casy like Jesus Christ is a man full of love for the people and can sacrifice own life for the people's suffering. There are many similarities between Casy and Christ, one of them is that Casy has also left to the forests in order to get what we called "soul-search" and discover the answers which are behind the questions. In this situation, Casy claims the comparison of Christ's and his actions to the Joad family, “...I been in the hills, thinkin', almost you might say like Jesus went into the wilderness to think His way out of a mess of troubles." (Steinbeck, 2000, p231) Casy further goes on during his rather rambling grace giving to Grandpa Joad, "I got tired like Him... I got mixed up like Him... I went into the wilderness like Him, without no campin' stuff."(Steinbeck, 2000, p88) Because of his frank character, Casy is openly accepted. We can see that he and Jesus Christ have some similarities. Steinbeck continues this strategies to let the reader come to consider that Casy is indeed to be the Christ figure of this novel. Casy and Jesus both see a common goodness and saw everyone as holy spirit and they all face struggles between their ideals versus the real world. Yet another similar point between them can be found when Casy decides to take adventure and join a group in order to stop strike wages from falling. This represents that Casy, just like Jesus and his faithful fellows, who follow him, is in an energy to preach their beliefs through the people. Meanwhile, there were many person who wanted to follow Jesus and his quest, and they declined due to fear of persecution, the same thing appears to Casy. And the third similarity between Jim Casy and Jesus Christ is the Casy's sacrifice. Steinbeck uses the character of Jim Casy as a media to emphasize the religion's importance in people's lives at hardship times. While the family can keep going just because Joad's unity and faith in God And proclaims new message by Jim Casy as his spokesman. But John Steinbeck lets Jim Casy die at last. The purpose of doing this is very clear, that is to tell the readers that through the Jesus-like preaching it is not possible to save this evil world, the only outcome is just like Jesus Christ's sacrifice of his own life to save the people. That is to say, Jim Casy is a scapegoat, just like Jesus Christ' experience, created by the author to suffer the death in place of the whole human beings.

John Steinbeck wants to show us that what he Jim Casy is facing is just like what Jesus Christ had faced. In the past, when the world was in this kind of situation, usually a scapegoat would be demanded to solve the problem. So in this novel a scapegoat is needed as well. So the burden of sacrificing for human being loads on the shoulder of Jim Casy. So from this point we will see this similarity clearly.

\section{ARCHETYPAL IMAGES}

The prose narrative pattern of the The Grapes of Wrath is outlined by a series of archetypal images. Steinbeck employed these images to strengthen the theme of wrath. The title of the novel The Grapes of Wrath has its tight connection with the Bible, wherein the symbol of the "grapes" has frequent appearance and rich contextual evocations. He adroitly utilizes the symbol of the "grapes" to extract from Western people's religious background various overlapping biblical images, thereby adds extra persuasive power to its theme. By the title of the novel we might naturally become aware of the importance of archetypal images as a main artistic technique, hence the relevance to devote special concern and care in analyzing. There is some most important images conspicuously jump into our horizon: the rain, water and flood; the grapes and other archetypal images.

A great deal has been written about John Steinbeck's use of biblical symbolisms in The Grapes of Wrath. However, one symbolic pattern---the rain, water and flood archetype---that comes from the Judaeo-Christian tradition has not been adequately dealt with. Therefore, a comprehensive examination of the rain, water and flood archetype as used by Steinbeck, particularly in Chapter Twenty-nine of the novel, will undoubtedly make a great contribution to the deeper understanding of the whole novel, especially the final chapter of the work. On the first stage, the aim of Steinbeck's use of rain, water and flood imagery is to underscore the tragic overtones of the novel. In showing the image as a destroyer before developing the creative power of the symbol, Steinbeck uses the motif structurally, so that the readers can be carried from the tragedy of the first part of the novel to the regenerative scene of the final chapter. In the final chapter of 
the novel, Steinbeck arranges the destructive features of the rain, water and flood archetype in a pattern of hierarchical importance. The water destroys the nature, the works of man, and even the man himself. And here in the novel, the description of the destructive forces of the rain, water and flood reverses the Biblical account of creation. In the Bible, the first three days are day of separation: light from darkness, the water above and the below, and the dry lands from the water. Yet in this final part of the novel, John Steinbeck mingles light and darkness in gray, the waters above and those below in a flood, and the land and water in mud. The purpose of this account is to create an apocalyptic vision of chaos and destruction. Steinbeck continues his descriptions of the destructive forces of the rains. They not only affect the God's creation, Nature, but also man's as well. The rains not only "brought down the trees", but also "bent the willows deep in the current". They also "poured over the highways", "wet the beds and blankets", "fouled the carburetors". Finally, the rains begin to destroy man himself.

Another important archetypal image is the "grapes". By its title we might naturally become aware of its significance as a central symbol in the novel. Therefore, it deserves special concern and care in our analysis of this image. Undoubtedly the title comes from Battle Hymn of the Republic, as many critics have pointed out in great clarion. According to Benson's Biography of Steinbeck, Steinbeck insisted to Covici, a publisher, that all the verses and music of Battle Hymn of the Republic be printed in the first edition of the The Grapes of Wrath. It was from this hymn that Steinbeck's first wife Carol strongly recommended its title. It is necessary to discuss the grape as a valuable symbol and its connection with Battle Hymn of the Republic. Yet, by the face that Battle Hymn of the Republic itself has deep biblical allusions and significance and the grape, as a symbol, has been referred to many times in the Bible, and has, therefore, strong evocations in western readers' religious unconscious, we should devote much of this writing to discuss the relationship between the symbol of the grape and the Bible in its religious sense. Finally, we will cite an Israel's military attack, coded by The Grapes of Wrath, to see the interesting impact that John Steinbeck has created on Westerner's religious sub-consciousness and the great influence of The Grapes of Wrath in western world, hence, the influence of the "grapes" a symbol. The word "grape" has various levels of implications in the Holy Bible. One of the symbolic meaning s of "grapes" can be seen in the The Song of Solomon. It is clear that Jesus Christ regards himself as "the true vine", his people as "branches beareth fruit", or "branches beareth grapes", and the relationship between Himself and his people as "you in me, and I in you". Steinbeck adroitly applies this symbolic meaning of "his people" to the inflicted, devastated tenant farmers, using "grapes" referring to the people. Yet, the "grapes" also symbolizes abundance and hope in the Bible. In the Old Testament Numbers Moses sent his disciples, Joshua and Oshes, to spy out the land of Canaan, and sid onto Oshea the son of Nun Jehoshua. Steinbeck uses this level of symbolic meaning of "grapes" for abundance, as above mentioned that the one huge cluster of grapes which Joshua and Oshea bring back from their first excursion into the rich land of Canaan is a symbol of plenty, a cluster so huge. It is this meaning of grapes that is frequently alluded to by Grampa Joad: "Gonna get me a whole big bunch a grapes off a bush, wo whatever, an' I'm gonna squash' em on my face an' let'em run offen my chin.” (Steinbeck, 2000, p 188)

However, in the Bible the "grapes" has another archetypal meaning. It is precisely this symbolic meaning that tightly connects the novel's title The Grapes of Wrath with Battle Humn of the Republic. In the Bible the "grapes" also contains the meaning of pain, wrath, and revenge. In Deuteronomy:" For their vine is of the vine of Sodom and of the fields Gomorrah: their grapes are grapes of gall, their clusters are bitter. Their wine is the poison of dragons and the cruel venom of asps...". In Jeremiah: "The fathers have eaten sour grapes, and their children's teeth are set on edge."(Steinbeck, 2000, p 107) In Revelation: And the angel thrust in his sickle into the earth, and gathered the grapes of the earth, and cast it into the great winepress of the wrath of God." "If any man worship the beast and his image, and receive his mark in his forehead, or in his hand, the same shall drink of the wine of the wrath of God, which is poured out without mixture into the cup of his indignation." (Steinbeck, 2000, p.79) imilarly, this meaning of the symbol is stated in the novel's inter-chapters: "In the souls of the people the grapes of wrath are filling and growing heavy, heavy for the vintage." (Steinbeck, 2000, p105)The title of the novel, as mentioned above, has tight connection with the symbolic images in Battle Hymn of the Republic, which evokes in vision and in feeling an invincible army marching on to victory. And so the Joads and their brothers, in their increasing frustrations and sufferings, are depicted, as an army growing in ever more militant wrath toward an irrevocable demand for restitution and comfort. The symbolic meanings of the "grapes" and its evocations have sustaining impact on the Westerners' religious psyche for its biblical origin, its popularity through Battle Hymn of the Republic, and most importantly the shaking influence of world masterpiece The Grapes of Wrath. Therefore, we now might have little puzzle why Israel coded his intrusion into Lebanon as "grapes of wrath". From April 11, 1996 to April 27, 1996, Israel, using aircraft and helicopters, dropped twenty-five thousand shells on the narrow land of Lebanon. By naming the war as "grapes of wrath", Israel government successfully evokes an image of an invincible people marching on to victory from long inflictions and oppressions in the westerners' religious sub-consciousness, thereby obscures the cruelty and the bloody massacre of war. This is a case of political maneuvers. Yet, it still manifests the wide-spreading influence of Steinbeck's novel The Grapes of Wrath and the symbol of the "grapes" in the westerners' psyche.

\section{CONCLUSION}

All in all, it is obvious enough that Jim Casy is a notable Christ figure in this novel. His Christ-like prophet function is verified in quite a few ways: his initials, J.C.; his continual soul searching in the wilderness; his announcement of the 
new religion; his discipline of Tom Joad toward him; his substitution of his own body for Tom's to go prison; and finally his persecution and death crying out, which is in essence a martyrdom for the people whom he has led and comforted and fought for. So Jim Casy is clearly a modern Christ figure, and he fulfills this identity through both his words and actions. The new messiah arrives in a rich context of tradition Christian symbology, and his messages, like that of Christ, are one that considerably broadens man's sense of spiritual community.

\section{REFERENCES}

[1] C.G.Jung. (2008). The Archetypes and The Collective Unconscious, Beijing: China Social Science Publishing House.

[2] Jung.Carl. (1996). Psychology and Literature. In $20^{\text {th }}$ Century Literary Criticism. Singapore: Longman et Singapore Publishers.

[3] Northrop.Frye. (2002). The Great Code: the Bible and Literature. San Dieg et New York et London: Harcourt Brace Jovanovich, Publishers.

[4] Richard. Hardin, F. (2004). Archetypal Criticism in Contemporary Literary Theory. Massachusetts: The University of Massachusetts Press

[5] Steinbeck. John. (1995). The Grapes of Wrath. NY: Everymen's Library.

[6] The New Testament. (1989). Hong Kong: Bible Society.

[7] Zhang Zhongzai. (2005). Selected Readings in Classical Western Critical Theory. Beijing: Foreign Language Teaching and Research Press.

[8] Zhugang. (1997). Western Literary Criticism. Dalian: Dalian Foreign Language Institute Publication.

Yanhong Fan was born in Changchun Jilin Province, China on June 12th, 1982, who has got a degree of Master of Arts in foreign language and literature from Liaoning Normal University, Dalian, Liaoning Province, China in 2008.

As a LECTURER, she teaches Contemporary English of the English major at School of Foreign Languages, Changchun University of Science and Technology. One book (as an editor) is as follows: [1] Selected Readings from British Literature (Beijing Institute of Technology Press, 2011). 